\title{
EFFECT OF EQUILIBRATION DURATION, VAPOUR TEMPERATURE AND EXPOSURE VAPOUR DURATION ON CRYOPRESERVED SPERM OF AFRICAN CATFISH
}

\author{
Noor Azlina, K. ${ }^{1}$, Wan Khadijah, W.E. ${ }^{2 *}$ and Abdullah, R.B. ${ }^{2}$ \\ ${ }^{1}$ Department of Biological Sciences, Faculty of Science and Technology, Universiti Malaysia Terengganu, \\ 21030 Kuala Terengganu, Malaysia \\ ${ }^{2}$ Animal Biotechnology-Embryo Laboratory (ABEL), Institute of Biological Sciences, Faculty of Science, \\ University of Malaya, 50603 Kuala Lumpur, Malaysia \\ *wkhadi@um.edu.my (corresponding author)
}

\begin{abstract}
The objective of this study was to obtain the optimal freezing rate with special focus on equilibration duration, vapour temperature and exposure vapour duration on sperm motility characteristics (SMCs) of African catfish (Clarias gariepinus) using Fish-Ringer Extender (FRE) with fixed 10\% Dimethyl-sulfoxide (DMSO) as cryoprotectant. Briefly, the straws containing the sperm were placed in a refrigerator at $4^{\circ} \mathrm{C}$ with three equilibration durations $(120,140$ or $160 \mathrm{~min})$ after which exposed to liquid nitrogen vapour at three vapour temperatures $\left(-80,-90\right.$ or $\left.-100^{\circ} \mathrm{C}\right)$ with three exposure vapour durations $(5$, 10 or $15 \mathrm{~min}$ ). Finally, the straws were directly plunged into liquid nitrogen vapour at $-196^{\circ} \mathrm{C}$. The frozen sperm were thawed at $30^{\circ} \mathrm{C}$ for $30 \mathrm{sec}$ to evaluate the sperm movement characteristics using the Automated Semen Analyzer-IVOS (Hamilton Thorne, USA). Results showed that the highest values of total motility and progressive motility obtained were combination factors of 120 min equilibration duration, $-100^{\circ} \mathrm{C}$ vapour temperature and $15 \mathrm{~min}$ vapour exposure duration $(87.44 \pm 2.07 \%$ and $28.22 \pm 2.16 \%$, respectively). Combination of $120 \mathrm{~min},-100^{\circ} \mathrm{C}$ and $15 \mathrm{~min}$ gave the highest value of rapid velocity (38.56 $\pm 3.10 \%)$, while combination of $120 \mathrm{~min},-80^{\circ} \mathrm{C}$ and $10 \mathrm{~min}$ gave the lowest value $(16.33 \pm 3.21 \%)$. The highest values of Velocity Average Path (VAP), Straight-line Velocity (VSL) and Curvilinear Velocity (VCL) were attained by combination of $120 \mathrm{~min},-80^{\circ} \mathrm{C}$ and $15 \mathrm{~min}$ which produced $68.76 \pm 6.42 \%, 60.49$ $\pm 6.01 \%$ and $94.71 \pm 6.27 \%$, respectively. For combination of $120 \mathrm{~min},-100^{\circ} \mathrm{C}$ and $15 \mathrm{~min}$ was probably the optimum condition in which positive correlations were shown between total motility and progressive motility; total motility and rapid; total motility and VAP; total motility and VSL; total motility and VCL; progressive motility and rapid; progressive motility and VAP; progressive motility and VSL; progressive motility and VCL; rapid and VAP; rapid and VSL; rapid and VCL; static and Straightness (STR); VAP and VSL; VAP and VCL; VSL and VCL and STR and Linearity (LIN) ( $p>0.05)$. In conclusion, under the present conditions, the optimal frozen-thawed sperm motility characteristics in African catfish using FRE extender was obtained with combination of 120 min equilibration duration, $-100^{\circ} \mathrm{C}$ vapour temperature and 5 to 15 min exposure vapour duration. It is recommended that FRE extender using DMSO as cryoprotectant apparently is suitable to cryopreserve the sperm of African catfish (Clarias gariepinus).
\end{abstract}

\begin{abstract}
ABSTRAK Matlamat kajian ini adalah untuk mendapatkan kadar penyejukbekuan yang optimum dengan merujuk khusus kepada tempoh pengimbangan, suhu pengewapan serta tempoh pendedahan kepada wap nitrogen cecair ke atas ciri-ciri motiliti sperma keli Afrika (Clarias gariepinus) menggunakan ekstender FRE yang ditetapkan pada 10\% Dimethyl-sulfoxide (DMSO) sebagai krioprotektan. Secara ringkas, straw yang mengandungi sperma diletakkan ke dalam peti sejuk pada suhu $4^{\circ} \mathrm{C}$ dalam tiga tempoh pengimbangan $(120,140$ atau $160 \mathrm{~min})$ dan seterusnya didedahkan kepada wap nitrogen cecair pada tiga suhu pengewapan $\left(-80,-90\right.$ atau $\left.\quad-100^{\circ} \mathrm{C}\right)$ dan tiga tempoh pendedahan $(5,10$ atau $15 \mathrm{~min})$. Berikutnya, straw dijunamkan secara langsung ke dalam nitrogen cecair pada suhu $-196^{\circ} \mathrm{C}$. Sperma yang telah mengalami proses penyejukbekuan dinyahsejukbekukan pada suhu $30^{\circ} \mathrm{C}$ selama 30 saat untuk menganalisis ciri-ciri motiliti sperma menggunakan penganalisis semen automatik (IVOS; Hamilton Thorne, USA). Keputusan menunjukkan bahawa nilai peratusan tertinggi bagi motiliti keseluruhan dan motiliti progresif dicapai oleh kombinasi faktor bagi 120 min tempoh pengimbangan, $-100^{\circ} \mathrm{C}$ suhu pengewapan dan 15 min tempoh pendedahan terhadap wap nitrogen cecair $(87.44 \pm 2.07 \%$ dan $28.22 \pm 2.16 \%$, masing-masing). Kombinasi $120 \mathrm{~min},-100^{\circ} \mathrm{C}$ dan $15 \mathrm{~min}$ memperoleh nilai peratusan tertinggi bagi pergerakan pantas $(38.56 \pm 3.10 \%)$, manakala kombinasi $120 \mathrm{~min},-80^{\circ} \mathrm{C}$ dan $15 \mathrm{~min}$ memperoleh nilai peratusan yang terendah $(16.33 \pm$ 3.21\%). Nilai peratusan tertinggi bagi "Velocity Average Path (VAP)", "Straight-line Velocity (VSL)" dan
\end{abstract}


“Curvilinear Velocity (VCL)" dicatatkan oleh kombinasi $120 \mathrm{~min},-80^{\circ} \mathrm{C}$ dan 15 min yang menghasilkan $68.76 \pm 6.42 \%, 60.49 \pm 6.01 \%$ dan $94.71 \pm 6.27 \%$, masing-masing. Kombinasi 120 min, $-100^{\circ} \mathrm{C}$ dan 15 min merupakan keadaan optimum di mana perhubungan positif ditunjukkan oleh motiliti keseluruhan dan motiliti progresif; motiliti keseluruhan dan pergerakan pantas; motiliti keseluruhan dan VAP; motiliti keseluruhan dan VSL; motiliti keseluruhan dan VCL; motiliti progresif dan pergerakan pantas; motiliti progresif dan VAP; motiliti progresif dan VSL; motiliti progresif dan VCL; pergerakan pantas dan VAP; pergerakan pantas dan VSL; pergerakan pantas dan VCL; pergerakan statik dan pergerakan mendatar (STR); VAP dan VSL; VAP dan VCL; VSL dan VCL dan STR dan Lineariti (LIN) ( $p>0.05$ ). Kesimpulannya, dalam keadaan sekarang, ciri-ciri motiliti sperma yang optimum bagi sejukbekunyahsejukbeku keli Afrika menggunakan FRE ekstender dicatatkan oleh kombinasi 120 min tempoh pengimbangan, $-100^{\circ} \mathrm{C}$ suhu pengewapan dan 5 hingga 15 min tempoh pendedahan kepada nitrogen cecair. Adalah dicadangkan bahawa FRE ekstender menggunakan DMSO sebagai krioprotektan mempamerkan kesesuaian dalam krioawetan sperma keli Afrika (Clarias gariepinus).

(Keywords: Cryopreservation, Sperm, Clarias gariepinus, Fish-Ringer Extender, Equilibration, Vapour Exposure)

\section{INTRODUCTION}

Sperm cryopreservation is an important technique to aid the management of controlled reproduction in fish farming, allowing storage of semen from selected species and individuals, shipment of genetic material, conservation of endangered species, self-fertilisation of protandrous fish and hybridization of species with non-overlapping reproductive periods $[1,2$, $3,4,5]$.

In Malaysia, African catfish is unknown for potential aquaculture candidate due to high survivability without oxygen and faster propagation rate. This species is also believed to have medicinal values as it can improve rehabilitation process of heart-disease patient after surgery. The ease of aquaculture farming and medicinal values has stimulated interest in production of this species. Traditionally, farmers have to sacrifice the males of African catfish in order to collect semen for fertilization with eggs. The lack of quality gamete and less male broodstock to gain maturity trigger a problem in reproduction of this species. Thus, through the application of sperm cryopreservation, it is hoped we can solve the problems of obtaining quality sperm for fertilisation as well as for maintaining the genetic collection (gene bank) of this species for future usage.

Remarkable factors affecting sperm cryopreservation have extensively been studied and reviewed by many researchers $[6,7,8,9,10$, $11,12]$. The most crucial factors that are critically inter-dependent with each other are composition of extender, cryoprotectant, equilibration duration and cooling rate. The stepwise process of temperature reduction is important to avoid cold-shock during freezing process. The interval for the sperm and extender to mix and to allow reduction of temperature slowly in order to prepare for the freezing processes is called equilibration, which presumably can avoid cold shock during freezing. Cooling rate is the rate of gradually decreasing a temperature during the cryopreservation process in which a single-stage and multiple-stage procedures have been developed $[6,8]$. In their studies, the cooling rate was determined by the height of the tray or the depth at which canisters were placed.

Previously, Tris-Citrate Acid Yolk Extender (TCAYE) has been used as a diluent to cryopreserve sperm of this species [12]. From our findings, TCAYE extender tends to form sperm-egg yolk agglutination which apparently interfere the function of Semen Analyzer-IVOS to analyse the sperm motility characteristics (SMCs) as egg yolk agglutinates when water were added during sperm activation. Therefore, the present study was done using FRE extender as an alternative diluent. The first attempt to cryopreserve sharptooth catfish, Clarias gariepinus using Ginzburg Fish Ringer were conducted in 2000 [9]. A similar finding was done on Torr tombraides sperm, which the sperm were successfully cryopreserved using modified Fish-Ringer Solution (mFRS) [10]. The present study was designed to explore into the potential of FRE extender to cryopreserve the sperm of African catfish (Clarias gariepinus). It evaluated the effects of different equilibration 
intervals, vapour temperatures and vapour durations on sperm movement characteristics.

\section{MATERIALS AND METHODS}

\section{Fish stocks and acclimatization}

Eighty sexually mature adult males of African catfish, Clarias gariepinus, (aged between 1-2 years; body weight of 1-2 kg), established for this study were bought from a local fish farm in Rembau, Negeri Sembilan. Acclimatisation was carried out in a fiberglass tank in the fish house at Institute of Biological Sciences Mini (Livestock) Farm, the University of Malaya. The broodstocks were hand-fed with "commercial finisher layer mash" twice a day, ad libitum and daily monitored.

\section{Hormonal induction}

Ovaprim (Syndel, Vancouver, Canada) $\{0.5 \mathrm{~mL} /$ $\mathrm{kg}$ body weight $(\mathrm{BW})\}$ was injected intramuscularly into the dorsal muscle of catfish. Before injection, wet towel was used to cover the head of the catfish in order to keep it quiet during injection. To avoid aggressive interaction between fish after receiving the hormone treatment, males were individually housed in separate tanks.

\section{Collection of milt}

Two individual males were sacrificed (euthanasia) for each semen collection and the body surface was thoroughly dried after which the testis was dissected out. Then, the milt was rapidly perforated out from the testis using a needle. The whitish-like semen was flowing out and the semen was collected using eppendorf tube. The motility percentage of fresh sperm was observed with subjective estimation (counting) under light microscope using 40x magnification.

\section{Semen dilution and loading}

After collection, the semen was diluted with Fish-Ringer Extender (FRE) with 10\% Dimethyl-sulfoxide (DMSO) in a ratio of (1:10). The composition of FRE extender is shown in Table 1. Then, the mixture of semen and extender was homogenously mixed. The diluted sperm was loaded into $0.25 \mathrm{~mL}$ French straw and some air space was left in between. Each end of the straws was sealed with an electric-sealer and subsequently, these straws were arranged on a special rack for freezing.

Table 1. The composition of Fish-Ringer Extender used in this study which was described by [10]

\begin{tabular}{cc}
\hline Chemical Substances & $\begin{array}{c}\text { Amount }(\mathrm{g} / 100 \\
\mathrm{mL})\end{array}$ \\
\hline $\mathrm{NaCl}$ & 0.750 \\
$\mathrm{KCl}$ & 0.100 \\
$\mathrm{CaCl}_{2}$ & 0.016 \\
$\mathrm{MgSO}_{4}$ & 0.023 \\
$\mathrm{NaH}_{2} \mathrm{PO}_{4}$ & 0.041 \\
$\mathrm{Glucose}$ & 0.100 \\
\hline
\end{tabular}

\section{Sperm cryopreservation and thawing}

The straws filled with semen-diluent were arranged on the freezing rack and placed into a refrigerator at $4^{\circ} \mathrm{C}$ for three equilibration intervals $(120,140$ or $160 \mathrm{~min})$. After equilibration in refrigerator, the straws were exposed to liquid nitrogen vapour at three duration intervals $(5,10$ or $15 \mathrm{~min})$ and three vapour temperatures $\left(-80,-90\right.$ or $\left.-100^{\circ} \mathrm{C}\right)$. Then, the straws were completely plunged into the liquid nitrogen at $-196^{\circ} \mathrm{C}$ for $10 \mathrm{~min}$. Next, the straws were kept in the liquid nitrogen tank for long-term sperm storage until analysis. Prior to analysis, the straws containing frozen-sperm were thawed in the water bath at $30^{\circ} \mathrm{C}$ for $30 \mathrm{sec}$ to defreeze the sperm from ice.

\section{Analysis of sperm motility characteristics}

Post-thawed cryopreserved sperm were analyzed using the "Automated Semen Analyzer-IVOS" (Hamilton-Thorne, USA) to evaluate the sperm movement characteristics. The parameters which were assessed include total motility, progressive motility, velocity distributions (rapid, medium, slow and static), sperm motion characteristics \{VAP (velocity average path), VCL (curvilinear velocity), VSL (straight-line velocity), LIN (the linearity), ALH (amplitude of lateral head displacement), BCF (beat-cross frequency) and STR (straightness) \}.

\section{Experimental design}

The goal of this experiment was to determine the effect of equilibration duration, vapour temperature and vapour exposure duration on post-thawed cryopreserved sperm motility characteristics in African catfish using FRE extender. Semen was collected from testis of 
sacrificed catfish, diluted in a ratio of 1:10 in 0.5 $\mathrm{ml}$ or $0.25 \mathrm{ml}$ French straws, subsequently; the straws containing the diluted semen were subjected to freezing process. This research involved a 3 x 3 x 3 factorial experiment consisting of three equilibration durations (120, 140 or $160 \mathrm{~min}$ ), three vapour temperatures $(-80$, -90 or $-100^{\circ} \mathrm{C}$ ) and three vapour exposure durations $(5,10$ or $15 \mathrm{~min})$. The molarity of cryoprotectant was fixed at $10 \%$ DMSO as described [10]. Each of the combination treatments was replicated three times with five observations per replicate. Sperm motility characteristics after freezing were evaluated using an Automated-Semen Analyzer (IVOS; Hamilton-Thorne, USA). Correlations among the sperm movement characteristics were made for the highest and the lowest total motility of frozen-thawed sperm for the combinations of equilibration duration, vapour temperature and vapour exposure duration obtained from this study.

\section{Statistical analysis}

All data were subjected to analysis of variance (ANOVA), followed by comparison of means using Duncan's Multiple Range Test (DMRT). All statistical analyses were performed using SPSS (Statistical Package for Social Sciences) for windows, version 12.0. The data were presented as mean \pm SEM. Pearson correlation was used to show relationship among the data which are significant at $\mathrm{p}<0.01$.

\section{RESULTS}

Table 2. Total motility and progressive motility (mean \pm SEM) of post-thawed cryopreserved sperm of African catfish (Claris gariepinus) using 10\% DMSO in FRE extender for combination of equilibration duration, vapour temperature and vapour exposure duration

\begin{tabular}{|c|c|c|c|c|c|}
\hline $\begin{array}{c}\text { Equilibration } \\
\text { duration (min) }\end{array}$ & $\begin{array}{l}\text { Vapour } \\
\text { temperature } \\
\left({ }^{\circ} \mathrm{C}\right)\end{array}$ & $\begin{array}{c}\text { Vapour } \\
\text { exposure } \\
\text { duration } \\
\text { (min) }\end{array}$ & $\mathrm{N}^{*}$ & $\begin{array}{c}\text { Total motility } \\
(\%)\end{array}$ & $\begin{array}{c}\text { Progressive motility } \\
(\%)\end{array}$ \\
\hline \multirow[t]{9}{*}{120} & -80 & 5 & 15 & $74.00 \pm 4.69^{\mathrm{abc}}$ & $20.00 \pm 2.59^{\mathrm{abc}}$ \\
\hline & & 10 & 15 & $62.73 \pm 6.95^{\mathrm{ab}}$ & $12.80 \pm 2.49^{\mathrm{a}}$ \\
\hline & & 15 & 13 & $59.92 \pm 9.11^{\mathrm{a}}$ & $15.77 \pm 3.63^{\mathrm{a}}$ \\
\hline & -90 & 5 & 13 & $71.38 \pm 9.76^{\mathrm{abc}}$ & $15.62 \pm 2.54^{\mathrm{a}}$ \\
\hline & & 10 & 15 & $80.80 \pm 4.54^{\mathrm{abc}}$ & $19.93 \pm 2.73^{\mathrm{abc}}$ \\
\hline & & 15 & 15 & $72.60 \pm 7.45^{\mathrm{abc}}$ & $19.93 \pm 2.71^{\mathrm{abc}}$ \\
\hline & -100 & 5 & 20 & $84.00 \pm 2.86^{\mathrm{bc}}$ & $25.95 \pm 2.36^{\mathrm{bc}}$ \\
\hline & & 10 & 20 & $80.95 \pm 3.71^{\mathrm{abc}}$ & $25.95 \pm 2.74^{\mathrm{bc}}$ \\
\hline & & 15 & 18 & $87.44 \pm 2.07^{\mathrm{c}}$ & $28.22 \pm 2.16^{\mathrm{c}}$ \\
\hline \multirow[t]{9}{*}{140} & -80 & 5 & 7 & $62.86 \pm 7.74^{\mathrm{ab}}$ & $14.00 \pm 3.51^{\mathrm{a}}$ \\
\hline & & 10 & 6 & $59.67 \pm 13.56^{\mathrm{a}}$ & $16.00 \pm 6.54^{\mathrm{a}}$ \\
\hline & & 15 & 7 & $78.29 \pm 7.51^{\mathrm{abc}}$ & $19.57 \pm 3.72^{\mathrm{abc}}$ \\
\hline & -90 & 5 & 15 & $73.73 \pm 5.17^{\mathrm{abc}}$ & $18.73 \pm 2.83^{\mathrm{ab}}$ \\
\hline & & 10 & 15 & $68.00 \pm 5.89^{\mathrm{abc}}$ & $16.13 \pm 2.35^{\mathrm{a}}$ \\
\hline & & 15 & 18 & $76.33 \pm 4.59^{\mathrm{abc}}$ & $20.00 \pm 2.18^{\mathrm{abc}}$ \\
\hline & -100 & 5 & 11 & $61.27 \pm 8.10^{\mathrm{a}}$ & $13.27 \pm 3.21^{\mathrm{a}}$ \\
\hline & & 10 & 15 & $59.27 \pm 8.00^{\mathrm{a}}$ & $13.53 \pm 2.87^{\mathrm{a}}$ \\
\hline & & 15 & 10 & $60.80 \pm 9.43^{\mathrm{a}}$ & $13.80 \pm 3.21^{\mathrm{a}}$ \\
\hline \multirow[t]{9}{*}{160} & -80 & 5 & 14 & $76.07 \pm 5.57^{\mathrm{abc}}$ & $15.64 \pm 2.67^{\mathrm{a}}$ \\
\hline & & 10 & 12 & $78.75 \pm 6.04^{\mathrm{abc}}$ & $20.08 \pm 2.74^{\mathrm{abc}}$ \\
\hline & & 15 & 12 & $73.75 \pm 4.76^{\mathrm{abc}}$ & $16.08 \pm 2.82^{\mathrm{a}}$ \\
\hline & -90 & 5 & 13 & $74.15 \pm 6.40^{\mathrm{abc}}$ & $16.08 \pm 1.95^{\mathrm{a}}$ \\
\hline & & 10 & 15 & $60.20 \pm 7.12^{\mathrm{a}}$ & $12.20 \pm 2.24^{\mathrm{a}}$ \\
\hline & & 15 & 19 & $73.21 \pm 4.50^{\mathrm{abc}}$ & $14.05 \pm 2.23^{\mathrm{a}}$ \\
\hline & -100 & 5 & 20 & $71.45 \pm 6.69^{\mathrm{abc}}$ & $18.60 \pm 2.66^{\mathrm{ab}}$ \\
\hline & & 10 & 19 & $80.00 \pm 3.65^{\mathrm{abc}}$ & $20.16 \pm 2.04^{\mathrm{abc}}$ \\
\hline & & 15 & 20 & $73.75 \pm 4.86^{\mathrm{abc}}$ & $17.80 \pm 2.00^{\mathrm{ab}}$ \\
\hline
\end{tabular}

$\mathrm{N}^{*}=$ Total number of observations (straws).

${ }^{\mathrm{abc}}$ Means with different superscripts within a column were significantly different $(\mathrm{p}<0.05)$. 
Fresh sperm (pre-freezing) of African catfish were estimated $100 \%$ motility rate under light microscope. The total motility and progressive motility of post-thawed cryopreserved sperm of African catfish using $10 \%$ DMSO in FRE extender for combination factors of equilibration duration, vapour temperature and vapour exposure duration are shown in Table 2.The highest values of total motility and progressive motility were obtained from combination factors of 120 min equilibration duration, $-100^{\circ} \mathrm{C}$ vapour temperature and $15 \mathrm{~min}$ vapour exposure duration $(87.44 \pm 2.07 \%$ and $28.22 \pm 2.16 \%$, respectively). Combinations of $140 \mathrm{~min},-100^{\circ} \mathrm{C}$ and $10 \mathrm{~min}$ showed the lowest values of total motility $(59.27 \pm 8.00 \%)$, but the lowest value of progressive motility was observed at combination of $160 \mathrm{~min},-90^{\circ} \mathrm{C}$ and $10 \mathrm{~min}$ $(12.20 \pm 2.24 \%)$.

As shown in Table 3, combination of $120 \mathrm{~min}$, $100^{\circ} \mathrm{C}$ and $15 \mathrm{~min}$ gave the highest value of rapid velocity $(38.56 \pm 3.10 \%)$, while combination of $120 \mathrm{~min},-80^{\circ} \mathrm{C}$ and $10 \mathrm{~min}$ gave the lowest value $(16.33 \pm 3.21 \%)$. For medium, slow and static velocities, the highest values were attained by combination of $120 \mathrm{~min},-100^{\circ} \mathrm{C}$ and $5 \mathrm{~min}$ $(11.75 \pm 1.29 \%), 160 \mathrm{~min},-80^{\circ} \mathrm{C}$ and $10 \mathrm{~min}$ $(44.92 \pm 3.34 \%)$ and $140 \mathrm{~min},-100^{\circ} \mathrm{C}$ and 10 $\min (40.73 \pm 8.00 \%)$, respectively. Both the lowest values of medium and slow velocities were shown for the combination of $140 \mathrm{~min}$, $80^{\circ} \mathrm{C}$ and $10 \mathrm{~min}(5.67 \pm 0.92 \%$ and $29.83 \pm$ $4.58 \%$, respectively). For static velocity, the highest value of static velocity was observed for combination of $140 \mathrm{~min},-100^{\circ} \mathrm{C}$ and $10 \mathrm{~min}$ $(40.73 \pm 8.00 \%)$, whereas the lowest value was shown for combination of $120 \mathrm{~min},-100^{\circ} \mathrm{C}$ and $15 \min (12.56 \pm 2.07 \%)$.

The highest values of VAP, VSL and VCL were attained by combination of $120 \mathrm{~min},-80^{\circ} \mathrm{C}$ and 15 min resulted $68.76 \pm 6.42 \%, 60.49 \pm 6.01 \%$ and $94.71 \pm 6.27 \%$, respectively. Whereas, the lowest values of VAP, VSL, VCL and ALH were shown by combination of $140 \mathrm{~min},-100^{\circ} \mathrm{C}$ and $15 \mathrm{~min}$ with respective values of $47.95 \pm$ $5.49 \%, 43.06 \pm 4.88 \%, 67.52 \pm 7.36 \%$ and 3.76 $\pm 0.70 \%$. In contrast, the combination of 160 $\min ,-80^{\circ} \mathrm{C}$ and $15 \mathrm{~min}$ gave the highest value of ALH. For value of BCF, combination of 120 $\min ,-80^{\circ} \mathrm{C}$ and 10 min was the highest $(15.26 \pm$ $4.17 \%$ ), while $120 \mathrm{~min},-80^{\circ} \mathrm{C}$ and $5 \mathrm{~min}$ obtained the lowest $(10.18 \pm 1.50 \%)$ (Table 4).

Table 5 gives the correlations among sperm motility characteristics for combination of 120 min equilibration duration, $-100^{\circ} \mathrm{C}$ vapour temperature and $15 \mathrm{~min}$ vapour exposure duration which was shown to be the optimum combination obtained in this study. Positive correlations were shown between total motility and progressive motility; total motility and rapid; total motility and VAP; total motility and VSL; total motility and VCL; progressive motility and rapid; progressive motility and VAP; progressive motility and VSL; progressive motility and VCL; rapid and VAP; rapid and VSL; rapid and VCL; static and STR; VAP and VSL; VAP and VCL; VSL and VCL and STR and LIN. In contrast, negative correlations were shown between total motility and static; total motility and STR; progressive motility and slow; progressive motility and static; rapid and slow; rapid and static; rapid and STR; slow and VCL; static and VAP; static and VSL; static and VCL; VAP and STR and VCL and STR.

Table 6 shows correlations among sperm motility characteristics for combination of 140 min equilibration duration $-100^{\circ} \mathrm{C}$ vapour temperature and $10 \mathrm{~min}$ vapour exposure duration (based on the lowest total motility of frozen-thawed sperm). It was noted that positive correlations were shown between total motility and progressive motility; total motility and rapid; total motility and medium; total motility and slow; progressive motility and rapid; rapid and medium; rapid and slow; medium and slow; VAP and VSL; VAP and VCL; VAP and LIN; VSL and VCL; VSL and LIN and STR and LIN. Inversely, the correlation of total motility and static; progressive motility and static; rapid and static; medium and static; slow and static; VAP and BCF; VSL and BCF; VCL and BCF; BCF and STR and BCF and LIN were negatively correlated. 
Table 3. Velocity distributions (mean \pm SEM) of post-thawed cryopreserved sperm of African catfish (Clarias gariepinus) using $10 \%$ DMSO in FRE extender for combination of equilibration duration, vapour temperature and vapour exposure duration

\begin{tabular}{|c|c|c|c|c|c|c|c|}
\hline $\begin{array}{l}\text { Equilibration } \\
\text { duration } \\
(\min )\end{array}$ & $\begin{array}{c}\text { Vapour } \\
\text { temperature } \\
\left({ }^{\circ} \mathrm{C}\right)\end{array}$ & $\begin{array}{l}\text { Vapour } \\
\text { exposure } \\
\text { duration } \\
\text { (min) }\end{array}$ & $\mathrm{N}^{*}$ & $\begin{array}{c}\text { Rapid } \\
(\%)\end{array}$ & $\begin{array}{c}\text { Medium } \\
(\%)\end{array}$ & $\begin{array}{c}\text { Slow } \\
(\%)\end{array}$ & $\begin{array}{c}\text { Static } \\
(\%)\end{array}$ \\
\hline \multirow[t]{9}{*}{120} & -80 & 5 & 15 & $25.13 \pm 3.18^{\mathrm{abc}}$ & $6.87 \pm 0.90^{\mathrm{abcd}}$ & $41.87 \pm 3.64^{\mathrm{abc}}$ & $26.00 \pm 4.69^{\mathrm{abcd}}$ \\
\hline & & 10 & 15 & $16.33 \pm 3.21^{\mathrm{a}}$ & $6.47 \pm 1.84^{\mathrm{abc}}$ & $39.93 \pm 3.90^{\mathrm{abc}}$ & $37.27 \pm 6.95^{\mathrm{bcd}}$ \\
\hline & & 15 & 13 & $21.54 \pm 5.08^{\mathrm{ab}}$ & $5.92 \pm 1.24^{\mathrm{ab}}$ & $32.54 \pm 3.79^{\mathrm{ab}}$ & $40.08 \pm 9.11^{\mathrm{d}}$ \\
\hline & -90 & 5 & 13 & $21.31 \pm 3.71^{\mathrm{ab}}$ & $11.23 \pm 1.74^{\mathrm{de}}$ & $38.85 \pm 5.49^{\mathrm{abc}}$ & $28.62 \pm 9.76^{\mathrm{abcd}}$ \\
\hline & & 10 & 15 & $26.73 \pm 3.28^{\mathrm{abc}}$ & $10.73 \pm 1.34^{\text {cde }}$ & $43.40 \pm 2.67^{b c}$ & $19.20 \pm 4.54^{\mathrm{abcd}}$ \\
\hline & & 15 & 15 & $25.60 \pm 3.53^{\mathrm{abc}}$ & $10.47 \pm 1.53^{\text {bcde }}$ & $36.60 \pm 3.77^{\mathrm{abc}}$ & $27.40 \pm 7.45^{\mathrm{abcd}}$ \\
\hline & -100 & 5 & 20 & $33.65 \pm 2.78^{\mathrm{bcd}}$ & $11.75 \pm 1.29^{\mathrm{e}}$ & $38.70 \pm 1.81^{\mathrm{abc}}$ & $16.00 \pm 2.86^{\mathrm{ab}}$ \\
\hline & & 10 & 19 & $34.21 \pm 3.53^{\mathrm{cd}}$ & $9.21 \pm 0.82^{\mathrm{abcde}}$ & $39.68 \pm 1.80^{\mathrm{abc}}$ & $16.79 \pm 3.10^{\mathrm{abc}}$ \\
\hline & & 15 & 18 & $38.56 \pm 3.10^{\mathrm{d}}$ & $10.22 \pm 0.53^{\mathrm{abcde}}$ & $38.56 \pm 1.75^{\mathrm{abc}}$ & $12.56 \pm 2.07^{\mathrm{a}}$ \\
\hline \multirow[t]{9}{*}{140} & -80 & 5 & 7 & $19.00 \pm 5.18^{\mathrm{a}}$ & $9.00 \pm 2.49^{\mathrm{abcde}}$ & $34.71 \pm 2.74^{\mathrm{abc}}$ & $37.14 \pm 7.74^{\text {bcd }}$ \\
\hline & & 10 & 6 & $24.00 \pm 9.94^{\mathrm{abc}}$ & $5.67 \pm 0.92^{\mathrm{a}}$ & $29.83 \pm 4.58^{\mathrm{a}}$ & $40.33 \pm 13.56^{\mathrm{d}}$ \\
\hline & & 15 & 7 & $26.71 \pm 5.57^{\mathrm{abc}}$ & $9.86 \pm 1.79^{\text {abcde }}$ & $42.00 \pm 4.55^{\mathrm{abc}}$ & $21.71 \pm 7.51^{\mathrm{abcd}}$ \\
\hline & -90 & 5 & 15 & $25.80 \pm 3.92^{\mathrm{abc}}$ & $8.80 \pm 0.94^{\mathrm{abcde}}$ & $39.07 \pm 3.35^{\mathrm{abc}}$ & $26.27 \pm 5.17^{\mathrm{abcd}}$ \\
\hline & & 10 & 15 & $20.27 \pm 2.71^{\mathrm{a}}$ & $6.27 \pm 0.91^{\mathrm{abc}}$ & $41.60 \pm 3.89^{\mathrm{abc}}$ & $32.00 \pm 5.89^{\mathrm{abcd}}$ \\
\hline & & 15 & 20 & $25.55 \pm 2.60^{\mathrm{abc}}$ & $10.20 \pm 0.89^{\text {abcde }}$ & $39.30 \pm 3.17^{\mathrm{abc}}$ & $24.80 \pm 4.23^{\mathrm{abcd}}$ \\
\hline & -100 & 5 & 11 & $17.91 \pm 4.14^{\mathrm{a}}$ & $7.36 \pm 1.65^{\text {abcde }}$ & $36.09 \pm 4.10^{\mathrm{abc}}$ & $38.73 \pm 8.10^{\mathrm{cd}}$ \\
\hline & & 10 & 15 & $17.13 \pm 3.54^{\mathrm{a}}$ & $7.20 \pm 1.43^{\mathrm{abcde}}$ & $34.80 \pm 4.19^{\mathrm{abc}}$ & $40.73 \pm 8.00^{\mathrm{d}}$ \\
\hline & & 15 & 10 & $16.40 \pm 3.84^{\mathrm{a}}$ & $6.70 \pm 1.49^{\mathrm{abcd}}$ & $37.90 \pm 5.80^{\mathrm{abc}}$ & $39.20 \pm 9.43^{\mathrm{d}}$ \\
\hline \multirow[t]{9}{*}{160} & -80 & 5 & 14 & $21.29 \pm 3.81^{\mathrm{ab}}$ & $10.50 \pm 1.10^{\mathrm{bcde}}$ & $44.36 \pm 4.63^{b c}$ & $24.00 \pm 5.56^{\mathrm{abcd}}$ \\
\hline & & 10 & 12 & $25.08 \pm 2.93^{\mathrm{abc}}$ & $8.67 \pm 1.39^{\text {abcde }}$ & $44.92 \pm 3.34^{\mathrm{bc}}$ & $21.25 \pm 4.76^{\mathrm{abcd}}$ \\
\hline & & 15 & 12 & $21.00 \pm 3.91^{\mathrm{ab}}$ & $8.58 \pm 1.20^{\mathrm{abcde}}$ & $44.33 \pm 4.03^{\mathrm{bc}}$ & $26.25 \pm 6.04^{\mathrm{abcd}}$ \\
\hline & -90 & 5 & 13 & $22.38 \pm 2.80^{\mathrm{abc}}$ & $10.46 \pm 1.44^{\text {bcde }}$ & $41.08 \pm 3.48^{\mathrm{abc}}$ & $25.85 \pm 6.40^{\mathrm{abcd}}$ \\
\hline & & 10 & 15 & $16.80 \pm 3.08^{\mathrm{a}}$ & $8.87 \pm 2.13^{\mathrm{abcde}}$ & $34.80 \pm 4.25^{\mathrm{abc}}$ & $39.80 \pm 7.12^{\mathrm{d}}$ \\
\hline & & 15 & 19 & $19.95 \pm 3.27^{\mathrm{a}}$ & $6.74 \pm 0.67^{\mathrm{abcd}}$ & $46.53 \pm 3.14^{\mathrm{c}}$ & $26.79 \pm 4.50^{\mathrm{abcd}}$ \\
\hline & -100 & 5 & 20 & $23.20 \pm 3.33^{\mathrm{abc}}$ & $9.10 \pm 1.02^{\text {abcde }}$ & $39.20 \pm 3.26^{\mathrm{abc}}$ & $28.55 \pm 6.69^{\mathrm{abcd}}$ \\
\hline & & 10 & 19 & $26.21 \pm 2.48^{\mathrm{abc}}$ & $10.21 \pm 0.85^{\mathrm{abcde}}$ & $43.79 \pm 1.37^{\mathrm{bc}}$ & $19.68 \pm 3.47^{\mathrm{abcd}}$ \\
\hline & & 15 & 17 & $21.59 \pm 2.74^{\mathrm{ab}}$ & $9.35 \pm 1.07^{\text {abcde }}$ & $42.71 \pm 2.56^{\mathrm{bc}}$ & $26.59 \pm 5.47^{\mathrm{abcd}}$ \\
\hline
\end{tabular}

$\mathrm{N}^{*}=$ Total number of observations (straws).

${ }^{\text {abcdef }}$ Means with different superscripts within a column were significantly different $(\mathrm{p}<0.05)$. 
Table 4. Sperm motion characteristics (mean \pm SEM) of post-thawed cryopreserved sperm of African catfish (Clarias gariepinus) using $10 \%$ DMSO in FRE extender for combination of equilibration duration, vapour temperature and vapour exposure duration

\begin{tabular}{|c|c|c|c|c|c|c|c|c|c|c|}
\hline $\begin{array}{l}\text { Equilibration } \\
\text { duration } \\
\text { (min) }\end{array}$ & $\begin{array}{c}\text { Vapour } \\
\text { temperature } \\
\left({ }^{\circ} \mathrm{C}\right)\end{array}$ & $\begin{array}{c}\text { Vapour } \\
\text { exposure } \\
\text { duration } \\
\text { (min) }\end{array}$ & $\mathrm{N}^{*}$ & $\begin{array}{c}\text { VAP } \\
(\mu \mathrm{m} / \mathrm{s})\end{array}$ & $\begin{array}{c}\text { VSL } \\
(\mu \mathrm{m} / \mathrm{s})\end{array}$ & $\begin{array}{c}\mathrm{VCL} \\
(\mu \mathrm{m} / \mathrm{s})\end{array}$ & $\begin{array}{l}\text { ALH } \\
(\mu \mathrm{m})\end{array}$ & $\begin{array}{l}\mathrm{BCF} \\
(\mathrm{Hz})\end{array}$ & $\begin{array}{c}\text { STR } \\
(\%)\end{array}$ & $\begin{array}{l}\text { LIN } \\
(\%)\end{array}$ \\
\hline \multirow[t]{9}{*}{120} & -80 & 5 & 15 & $66.92 \pm 5.13^{\mathrm{def}}$ & $54.30 \pm 3.76^{\mathrm{abc}}$ & $91.67 \pm 7.10^{\mathrm{de}}$ & $5.03 \pm 0.40^{\mathrm{abc}}$ & $10.18 \pm 1.50^{\mathrm{a}}$ & $86.33 \pm 2.70^{\mathrm{ab}}$ & $63.93 \pm 2.24^{\mathrm{ab}}$ \\
\hline & & 10 & 13 & $58.99 \pm 5.95^{\text {abcdef }}$ & $51.65 \pm 4.93^{\mathrm{abc}}$ & $81.42 \pm 7.40^{\text {abcde }}$ & $4.92 \pm 0.41^{\mathrm{abc}}$ & $15.26 \pm 4.17^{\mathrm{a}}$ & $87.69 \pm 1.88^{\mathrm{ab}}$ & $64.38 \pm 2.73^{\mathrm{ab}}$ \\
\hline & & 15 & 12 & $68.76 \pm 6.42^{\mathrm{f}}$ & $60.49 \pm 6.01^{\mathrm{c}}$ & $94.71 \pm 6.27^{\mathrm{e}}$ & $5.33 \pm 0.60^{\mathrm{abc}}$ & $10.64 \pm 1.59^{\mathrm{a}}$ & $88.00 \pm 1.64^{\mathrm{ab}}$ & $62.67 \pm 3.44^{\mathrm{ab}}$ \\
\hline & -90 & 5 & 13 & $52.37 \pm 3.10^{\text {abcd }}$ & $47.11 \pm 2.97^{\mathrm{ab}}$ & $72.58 \pm 3.78^{\mathrm{abc}}$ & $4.76 \pm 0.66^{\mathrm{abc}}$ & $12.52 \pm 1.27^{\mathrm{a}}$ & $88.92 \pm 1.54^{\mathrm{ab}}$ & $63.46 \pm 2.25^{\mathrm{ab}}$ \\
\hline & & 10 & 15 & $58.58 \pm 3.06^{\text {abcdef }}$ & $50.54 \pm 2.89^{\mathrm{abc}}$ & $79.93 \pm 3.91^{\text {abcde }}$ & $4.98 \pm 0.38^{\mathrm{abc}}$ & $11.94 \pm 0.71^{\mathrm{a}}$ & $87.00 \pm 0.78^{\mathrm{ab}}$ & $64.80 \pm 1.35^{\mathrm{ab}}$ \\
\hline & & 15 & 15 & $55.65 \pm 3.81^{\text {abcdef }}$ & $48.21 \pm 3.22^{\mathrm{abc}}$ & $75.75 \pm 4.76^{\mathrm{abcd}}$ & $5.72 \pm 0.65^{\mathrm{bc}}$ & $12.06 \pm 1.64^{\mathrm{a}}$ & $86.73 \pm 0.66^{\mathrm{ab}}$ & $64.93 \pm 2.13^{\mathrm{ab}}$ \\
\hline & -100 & 5 & 20 & $60.57 \pm 2.59^{\text {abcdef }}$ & $52.94 \pm 2.19^{\mathrm{abc}}$ & $82.77 \pm 3.32^{\text {abcde }}$ & $4.84 \pm 0.27^{\mathrm{abc}}$ & $12.50 \pm 0.81^{\mathrm{a}}$ & $87.35 \pm 0.63^{\mathrm{ab}}$ & $64.95 \pm 0.90^{\mathrm{ab}}$ \\
\hline & & 10 & 19 & $61.02 \pm 2.10^{\mathrm{abcdef}}$ & $53.22 \pm 1.71^{\mathrm{abc}}$ & $83.33 \pm 3.12^{\text {abcde }}$ & $5.08 \pm 0.40^{\mathrm{abc}}$ & $13.27 \pm 1.23^{\mathrm{a}}$ & $87.53 \pm 0.77^{\mathrm{ab}}$ & $65.42 \pm 1.67^{\mathrm{ab}}$ \\
\hline & & 15 & 18 & $64.50 \pm 2.79^{\text {bcdef }}$ & $55.72 \pm 2.25^{\mathrm{abc}}$ & $89.50 \pm 3.45^{\text {bcde }}$ & $5.08 \pm 0.20^{\mathrm{abc}}$ & $13.68 \pm 0.70^{\mathrm{a}}$ & $85.78 \pm 0.70^{\mathrm{a}}$ & $62.72 \pm 0.78^{\mathrm{ab}}$ \\
\hline \multirow[t]{9}{*}{140} & -80 & 5 & 7 & $50.14 \pm 4.97^{\mathrm{ab}}$ & $44.11 \pm 4.63^{\mathrm{a}}$ & $74.70 \pm 4.64^{\mathrm{abcd}}$ & $5.11 \pm 0.61^{\mathrm{abc}}$ & $13.31 \pm 1.58^{\mathrm{a}}$ & $86.86 \pm 1.10^{\mathrm{ab}}$ & $58.57 \pm 4.15^{\mathrm{a}}$ \\
\hline & & 10 & 6 & $57.98 \pm 10.62^{\text {abcdef }}$ & $47.20 \pm 9.49^{\mathrm{ab}}$ & $80.03 \pm 15.64^{\text {abcde }}$ & $6.47 \pm 1.60^{c}$ & $11.83 \pm 2.70^{\mathrm{a}}$ & $86.67 \pm 3.30^{\mathrm{ab}}$ & $66.83 \pm 6.18^{b}$ \\
\hline & & 15 & 7 & $67.19 \pm 6.98^{\mathrm{ef}}$ & $58.99 \pm 5.94^{\mathrm{bc}}$ & $92.17 \pm 6.35^{\mathrm{de}}$ & $5.54 \pm 0.29^{\mathrm{abc}}$ & $11.20 \pm 1.46^{\mathrm{a}}$ & $87.00 \pm 1.15^{\mathrm{ab}}$ & $63.00 \pm 2.50^{\mathrm{ab}}$ \\
\hline & -90 & 5 & 15 & $61.57 \pm 2.45^{\text {abcdef }}$ & $52.93 \pm 2.23^{\mathrm{abc}}$ & $85.21 \pm 3.08^{\text {abcde }}$ & $5.61 \pm 0.23^{\mathrm{bc}}$ & $12.53 \pm 0.63^{\mathrm{a}}$ & $85.47 \pm 0.57^{\mathrm{a}}$ & $62.40 \pm 0.88^{\mathrm{ab}}$ \\
\hline & & 10 & 14 & $51.77 \pm 4.04^{\mathrm{ab}}$ & $45.36 \pm 3.29^{\mathrm{a}}$ & $71.36 \pm 4.64^{\mathrm{ab}}$ & $4.61 \pm 0.43^{\mathrm{ab}}$ & $12.86 \pm 1.01^{\mathrm{a}}$ & $88.50 \pm 0.89^{\mathrm{ab}}$ & $64.57 \pm 1.32^{\mathrm{ab}}$ \\
\hline & & 15 & 18 & $57.97 \pm 2.16^{\text {abcdef }}$ & $50.68 \pm 1.79^{\mathrm{abc}}$ & $79.58 \pm 2.84^{\text {abcde }}$ & $5.13 \pm 0.28^{\mathrm{abc}}$ & $13.04 \pm 0.98^{\mathrm{a}}$ & $87.11 \pm 0.79^{\mathrm{ab}}$ & $64.11 \pm 0.96^{\mathrm{ab}}$ \\
\hline & -100 & 5 & 11 & $58.30 \pm 4.22^{\text {abcdef }}$ & $50.45 \pm 4.41^{\mathrm{abc}}$ & $84.67 \pm 4.83^{\text {abcde }}$ & $5.91 \pm 0.69^{\mathrm{bc}}$ & $11.13 \pm 1.58^{\mathrm{a}}$ & $84.64 \pm 2.10^{\mathrm{a}}$ & $61.36 \pm 4.12^{\mathrm{ab}}$ \\
\hline & & 10 & 15 & $53.55 \pm 4.86^{\text {abcde }}$ & $47.96 \pm 4.52^{\mathrm{abc}}$ & $72.70 \pm 5.34^{\mathrm{abc}}$ & $4.75 \pm 0.66^{\mathrm{abc}}$ & $11.91 \pm 1.46^{\mathrm{a}}$ & $88.20 \pm 0.93^{\mathrm{ab}}$ & $63.73 \pm 2.49^{\mathrm{ab}}$ \\
\hline & & 15 & 10 & $47.95 \pm 5.49^{\mathrm{a}}$ & $43.06 \pm 4.88^{\mathrm{a}}$ & $67.52 \pm 7.36^{\mathrm{a}}$ & $3.76 \pm 0.70^{\mathrm{a}}$ & $10.31 \pm 1.62^{\mathrm{a}}$ & $90.20 \pm 0.97^{\mathrm{b}}$ & $65.90 \pm 1.67^{\mathrm{ab}}$ \\
\hline \multirow[t]{9}{*}{160} & -80 & 5 & 14 & $53.34 \pm 4.49^{\text {abcde }}$ & $47.30 \pm 4.00^{\mathrm{ab}}$ & $75.36 \pm 4.67^{\mathrm{abcd}}$ & $5.39 \pm 0.51^{\mathrm{abc}}$ & $12.61 \pm 1.13^{\mathrm{a}}$ & $88.64 \pm 1.37^{\mathrm{ab}}$ & $61.86 \pm 2.70^{\mathrm{ab}}$ \\
\hline & & 10 & 12 & $66.71 \pm 4.67^{\text {cdef }}$ & $58.89 \pm 4.03^{\mathrm{bc}}$ & $90.73 \pm 4.81^{\text {cde }}$ & $6.22 \pm 0.47^{\mathrm{bc}}$ & $12.48 \pm 1.33^{\mathrm{a}}$ & $87.92 \pm 1.12^{\mathrm{ab}}$ & $64.17 \pm 1.01^{\mathrm{ab}}$ \\
\hline & & 15 & 11 & $59.29 \pm 2.68^{\text {abcdef }}$ & $51.94 \pm 2.64^{\mathrm{abc}}$ & $82.18 \pm 3.69^{\text {abcde }}$ & $6.03 \pm 0.26^{\mathrm{bc}}$ & $12.66 \pm 1.64^{\mathrm{a}}$ & $86.27 \pm 0.75^{\mathrm{ab}}$ & $61.55 \pm 1.12^{\mathrm{ab}}$ \\
\hline & -90 & 5 & 13 & $52.45 \pm 2.85^{\mathrm{abcd}}$ & $45.11 \pm 2.34^{\mathrm{a}}$ & $74.88 \pm 3.78^{\mathrm{abcd}}$ & $5.40 \pm 0.54^{\mathrm{abc}}$ & $12.90 \pm 1.39^{\mathrm{a}}$ & $86.00 \pm 0.60^{\mathrm{ab}}$ & $61.92 \pm 1.63^{\mathrm{ab}}$ \\
\hline & & 10 & 15 & $52.21 \pm 4.48^{\mathrm{abc}}$ & $44.77 \pm 3.88^{\mathrm{a}}$ & $72.57 \pm 5.32^{\mathrm{abc}}$ & $4.96 \pm 0.62^{\mathrm{abc}}$ & $14.24 \pm 2.25^{\mathrm{a}}$ & $86.67 \pm 1.26^{\mathrm{ab}}$ & $62.93 \pm 2.54^{\mathrm{ab}}$ \\
\hline & & 15 & 19 & $54.67 \pm 3.40^{\text {abcdef }}$ & $47.17 \pm 2.91^{\mathrm{ab}}$ & $77.35 \pm 4.21^{\text {abcde }}$ & $5.29 \pm 0.44^{\mathrm{abc}}$ & $13.77 \pm 1.24^{\mathrm{a}}$ & $85.74 \pm 0.79^{\mathrm{a}}$ & $61.11 \pm 1.67^{\mathrm{ab}}$ \\
\hline & -100 & 5 & 18 & $62.52 \pm 5.17^{\text {abcdef }}$ & $55.44 \pm 4.54^{\mathrm{abc}}$ & $82.39 \pm 6.21^{\text {abcde }}$ & $5.28 \pm 0.58^{\mathrm{abc}}$ & $14.34 \pm 1.60^{\mathrm{a}}$ & $88.67 \pm 0.98^{\mathrm{ab}}$ & $66.89 \pm 1.91^{b}$ \\
\hline & & 10 & 19 & $57.36 \pm 2.54^{\text {abcdef }}$ & $49.84 \pm 2.16^{\mathrm{abc}}$ & $79.38 \pm 3.48^{\text {abcde }}$ & $4.78 \pm 0.41^{\mathrm{abc}}$ & $13.25 \pm 1.42^{\mathrm{a}}$ & $87.47 \pm 0.79^{\mathrm{ab}}$ & $65.11 \pm 1.34^{\mathrm{ab}}$ \\
\hline & & 15 & 19 & $54.25 \pm 2.31^{\text {abcde }}$ & $48.32 \pm 2.02^{\mathrm{abc}}$ & $69.51 \pm 5.98^{\mathrm{a}}$ & $5.33 \pm 0.40^{\mathrm{abc}}$ & $14.11 \pm 0.79^{\mathrm{a}}$ & $88.37 \pm 1.05^{\mathrm{ab}}$ & $62.68 \pm 1.35^{\mathrm{ab}}$ \\
\hline
\end{tabular}

$\mathrm{N}^{*}=$ Total number of observations (straws).

${ }^{\text {abcdef }}$ Means with different superscripts within a column were significantly different $(\mathrm{p}<0.05)$. 
Table 5. Correlations among sperm motility characteristics of post-thawed cryopreserved sperm of African catfish (Clarias gariepinus) at combination of 120 min equilibration duration, $-100^{\circ} \mathrm{C}$ vapour temperature and $15 \mathrm{~min}$ vapour exposure duration

\begin{tabular}{|c|c|c|c|c|c|c|c|c|c|c|c|c|c|}
\hline & Total motility & $\begin{array}{c}\text { Progressive } \\
\text { motility }\end{array}$ & Rapid & Medium & Slow & Static & VAP & VSL & VCL & ALH & $\mathrm{BCF}$ & STR & LIN \\
\hline Total motility & 1 & $.802 * *$ & $.836 * *$ & .004 & -.313 & $-1.000 * *$ & $.703 * *$ & $.655^{* *}$ & $.701 * *$ & -.089 & -.411 & $-.488^{*}$ & .029 \\
\hline Progressive motility & & 1 & $.963 * *$ & -.142 & $-.728 * *$ & $-.802 * *$ & $.724 * *$ & $.698 * *$ & $.726 * *$ & -.250 & -.430 & -.313 & .167 \\
\hline Rapid & & & 1 & -.123 & $-.757 * *$ & $-.836 * *$ & $.767 * *$ & $.707 * *$ & $.811 * *$ & -.190 & -.440 & $-.529 *$ & -.033 \\
\hline Medium & & & & 1 & -.074 & -.004 & -.278 & -.310 & -.180 & .097 & .043 & .051 & -.312 \\
\hline Slow & & & & & 1 & .313 & -.449 & -.392 & $-.556^{*}$ & .206 & .287 & .344 & .176 \\
\hline Static & & & & & & 1 & $-.703 * *$ & $-.655^{* *}$ & $-.701 * *$ & .089 & .411 & $.488^{*}$ & -.029 \\
\hline VAP & & & & & & & 1 & $.983 * *$ & $.962 * *$ & .198 & -.331 & $-.590 * *$ & .064 \\
\hline VSL & & & & & & & & 1 & $.905^{* *}$ & .194 & -.318 & -.450 & .215 \\
\hline VCL & & & & & & & & & 1 & .214 & -.303 & $-.726 * *$ & -.170 \\
\hline ALH & & & & & & & & & & 1 & .364 & -.203 & -.272 \\
\hline $\mathrm{BCF}$ & & & & & & & & & & & 1 & .198 & -.067 \\
\hline STR & & & & & & & & & & & & 1 & $.641 * *$ \\
\hline LIN & & & & & & & & & & & & & 1 \\
\hline
\end{tabular}

No. of samples $=18$.

** Pearson correlations were significant $(\mathrm{p}<0.01)$

*Pearson correlations were significant $(\mathrm{p}<0.05)$. 
Table 6. Correlations among sperm motility characteristics of post-thawed cryopreserved sperm of African catfish (Clarias gariepinus) at combination of 140 $\underline{\text { min equilibration duration, }-100^{\circ} \mathrm{C} \text { vapour temperature and } 10 \mathrm{~min} \text { vapour exposure duration }}$

\begin{tabular}{|c|c|c|c|c|c|c|c|c|c|c|c|c|c|}
\hline & Total motility & $\begin{array}{c}\text { Progressive } \\
\text { motility }\end{array}$ & Rapid & Medium & Slow & Static & VAP & VSL & VCL & ALH & $\mathrm{BCF}$ & STR & LIN \\
\hline Total motility & 1 & $.828 * *$ & $.674 * *$ & $.643 * *$ & $.618^{*}$ & $-.741 * *$ & .170 & .107 & .280 & -.269 & -.205 & .229 & .091 \\
\hline Progressive motility & & 1 & $.830^{* *}$ & .464 & .344 & $-.632 *$ & .156 & .096 & .200 & -.226 & -.201 & .153 & .239 \\
\hline Rapid & & & 1 & $.631 *$ & $.536 *$ & $-.838 * *$ & .257 & .219 & .253 & -.242 & -.255 & .345 & .316 \\
\hline Medium & & & & 1 & $.755^{* *} *$ & $-.860 * *$ & -.075 & -.098 & -.015 & -.287 & .031 & .296 & -.047 \\
\hline Slow & & & & & 1 & $-.900 * *$ & -.090 & -.121 & -.024 & -.283 & -.049 & .297 & -.096 \\
\hline Static & & & & & & 1 & -.056 & -.019 & -.100 & .308 & .132 & -.365 & -.082 \\
\hline VAP & & & & & & & 1 & $.993 * *$ & $.965 * *$ & .484 & $-.654 * *$ & .311 & $.674 * *$ \\
\hline VSL & & & & & & & & 1 & $.943 * *$ & .486 & $-.693 * *$ & .381 & $.698 * *$ \\
\hline $\mathrm{VCL}$ & & & & & & & & & 1 & .353 & $-.569^{*}$ & .244 & .503 \\
\hline ALH & & & & & & & & & & 1 & -.183 & -.195 & .477 \\
\hline $\mathrm{BCF}$ & & & & & & & & & & & 1 & $-.747 * *$ & $-.733 * *$ \\
\hline STR & & & & & & & & & & & & 1 & $.545^{*}$ \\
\hline LIN & & & & & & & & & & & & & 1 \\
\hline
\end{tabular}

No. of samples $=15$.

** Pearson correlations were significant $(\mathrm{p}<0.01)$

*Pearson correlations were significant $(\mathrm{p}<0.05)$. 


\section{DISCUSSION}

The optimum combination factors were obtained at $120 \mathrm{~min}$ equilibration duration, $-100^{\circ} \mathrm{C}$ vapour temperature and $15 \mathrm{~min}$ vapour exposure duration which gave the highest total motility and progressive motility. At $120 \mathrm{~min}$ equilibration duration, the trends of total motility and progressive motility values increased as vapour temperature reduced within $15 \mathrm{~min}$ vapour exposure duration. At $140 \mathrm{~min}$ equilibration duration, the values of total motility and progressive motility were at peak under $90^{\circ} \mathrm{C}$ vapour temperature, but as the vapour temperature was lowered until $-100^{\circ} \mathrm{C}$, the total motility and progressive motility values reduced. There was a consistent trend in values of total motility and progressive motility at $160 \mathrm{~min}$ equilibration duration. The present study indicates equilibration duration and vapour temperature play an important role in sperm freezing process. Equilibration duration is required in sperm freezing process of African catfish, for number of reasons. At the initial stage of freezing, the extender solution is hyperosmatic while in the sperm cell is hyposmotic; consequently, the water molecules are pumped out from the sperm cell into the extender. The osmotic process makes the sperm cells shrink. Having an optimal equilibration temperature at $4^{\circ} \mathrm{C}$ is crucial to reduce the occurrence of cold-shock. In addition, cryoprotectant protects the sperm cells to form ice crystal internally by inhibiting cryo-injury during the freezing process.

The combination of $10 \%$ DMSO in FRE extender showed a promising result in total motility and progressive motility values. The current finding was supported by [10] which claimed the first report of the successful production of viable fry of Deccan mahseer (Tor khudree) from cryopreserved sperm using modified Fish Ringer solution and 5 to $15 \%$ DMSO at an equilibration time of 10 to $90 \mathrm{~min}$. In contrast, a study by [13], found combination of $10 \%$ methanol in Ringer extender maintained the highest post-thawed motility (65.00 \pm $5.00 \%)$, fertilisation $(90.47 \pm 3.67 \%)$ and hatching rate $(88 \pm 4 \%)$ of Yellow catfish (Pelteobagrus fulvidraco). Further refinement is needed to optimize the sperm motility characteristics result using different concentrations of DMSO and also different types and concentrations of cryoprotectants.
In the present study, equilibration plays a role in which $120 \mathrm{~min}$ is an optimal duration gave the highest total motility value of post-thawed cryopreserved sperm. It is probable that $120 \mathrm{~min}$ is the suitable duration to equilibrate the sperm because it produced relatively the highest total motility frozen-thawed sperm. According to [5], the effect of equilibration was significantly dependent on the type of cryoprotectant used; they observed that equilibration was not harmful in the case of DMA, whereas it significantly lowered the fertilising ability of cryopreserved sperm in rainbow trout when DMSO or ethylene glycol was used as cryoprotectants.

The pattern of sperm movement characteristics for 120 min gave a contrast correlations between total motility and VAP; total motility and VCL; medium and VAP; medium and ALH and ALH and BCF. However, at 140 minutes marked differences were found among correlations of progressive motility and VAP; progressive motility and VSL and progressive motility and VCL. The differences in pattern of correlations were shown also at $160 \mathrm{~min}$ among progressive motility and slow and static and LIN. Correlations among sperm motility characteristics of $-80,-90$ and $-100^{\circ} \mathrm{C}$ showed a slightly different in which $-80^{\circ} \mathrm{C}$ was found to have correlations among total motility and VAP; total motility and VSL; progressive motility and slow; rapid and slow; medium and VAP; medium and VSL; medium and VCL; slow and VAP; slow and VSL and ALH and BCF. However, at $-90^{\circ} \mathrm{C}$, it showed correlations among total motility and $\mathrm{BCF}$; medium and $\mathrm{BCF}$ and static and STR. At $-100^{\circ} \mathrm{C}$, only one correlation differ from $-80^{\circ} \mathrm{C}$ and $\quad-90^{\circ} \mathrm{C}$ that was shown correlation among VAP and LIN. The correlations among medium and VAP; medium and VCL and ALH and BCF were different at 10 min vapour exposure duration. Marked differences of pattern correlations were found at 15 min vapour exposure, between correlations of total motility and BCF; progressive motility and VSL; progressive motility and $\mathrm{BCF}$; rapid and VSL; medium and BCF and slow and BCF.

\section{CONCLUSION}

The combination of $10 \%$ DMSO in FRE extender gave the highest value of sperm survivability under $120 \mathrm{~min}$ equilibration duration, $-100^{\circ} \mathrm{C}$ vapour temperature and 5 to 15 min exposure vapour duration. 


\section{ACKNOWLEDGEMENT}

This work is part of research project of first author's Master of Biotechnology, which financially supported by PPP Research Grant (P0060 / 2008A), the University of Malaya, Malaysia.

\section{REFERENCES}

1. Morris G.J. (1981). Cryopreservation: an introduction to cryopreservation in culture collections. Cambridge (England): Institute of Terrestrial Ecology.

2. Fahy G.M. (1986). The relevance of cryoprotectant toxicity to cryobiology. Cryobiology.

23:1-13.

3. Jamieson B.G.M. (1991). Fish evolution and systematics from sperm. Cambridge University Press. Cambridge. p. 319.

4. Leung, L.K.P. and Jamieson B.G.M. (1991). Live preservation of fish gametes. In: Fish Evolution and Systematics: Evidence from Sperm, Jamieson BGM (Ed.), Cambridge University Press. pp. 245-269.

5. Babiak I., Glogowski J., Gorycko K., et al. (2001). Effect of extender composition and equilibration time on fertilisation ability and enzymatic activity of rainbow trout cryopreserved sperm. Theriogenology. 56: 177-192.

6. Chao N.H. (1991). Fish sperm cryopreservation in Taiwan: Technology advancement and extension efforts. Paper on International Symposium on Reproductive Biology in Aquaculture. Department of Aquaculture, Taiwan Fishery Research Institute,

Taiwan.

7. Chao N.H. and Liao I.C. (2001). Cryopreservation of finfish and shellfish gametes and embryos. Aquaculture. 197: 161-189.

8. Christensen J.M. and Tiersch T.R. (1996). Cryopreservation of channel catfish sperm: effect of cryoprotectant, straw size and extender formulation. Theriogenology. 47: 639-645.

9. Viveiros A.T.M., So N., et al. (2000). Sperm cryopreservation of African catfish, Clarias gariepinus: cryoprotectants, freezing rates and sperm: egg dilution ratio. Theriogenology. 54:1395-1408.

10. Basavaraja N. and Hedge S.N. (2004). Cryopreservation of the endangered mahseer (Tor khudree) sperm: Effect of extender composition, cryoprotectants, dilution ratio and storage period on post-thaw viability. Cryobiology. 49: 149-156.

11. Muchlisin Z.A. (2005). Review: current status of extenders and cryoprotectants on fish sperm cryopreservation. $\begin{array}{lll}\text { Biodiversitas. } & 6: & 12-15 \text {. }\end{array}$

12. Noor Azlina K. (2010). Effects of extenders, cryoprotectants, equilibration duration, vapour temperature and exposure vapour duration on freezability of African catfish (Clarias gariepinus) sperm. M.Biotech. Thesis. Institute of Biological Sciences, Faculty of Science, University of Malaya, Kuala Lumpur, Malaysia.

13. Pan J., Ding S., Ge J., et al. (2008). Development of cryopreservation for maintaining yellow catfish, Pelteobagrus fulvidraco sperm. Aquaculture. 279: 173-176. 